\title{
Identification of a human immunodominant T-cell epitope of mycobacterium tuberculosis antigen PPE44
}

\author{
Barbara Cuccu, Giulia Freer, Alessandro Genovesi, Carlo Garzelli and Laura Rindi*
}

\begin{abstract}
Background: Recently our group has identified a novel antigen of Mycobacterium tuberculosis, protein PPE44, belonging to the "PPE protein" family. Although its role in infection is largely unknown, PPE44-specific immune responses were detected in mice infected with M. tuberculosis; moreover, immunization of mice with PPE44 subunit vaccines resulted in protective efficacy comparable to the one afforded by BCG against $M$. tuberculosis (Romano et al., Vaccine 26, 6053-6063, 2008).

Results: In the present paper, we investigated anti-PPE44 T-lymphocyte responses during human infection by evaluating the frequency of PPE44-specific interferon (IFN)- $\gamma$-secreting cells by ELISpot and flow cytometry in a small cohort of healthy subjects that had proven positive to PPD $\left(\mathrm{PPD}^{+}\right)$in vitro, in patients with active tuberculosis, in subjects vaccinated with BCG and in unvaccinated, PPD healthy controls. We showed IFN- $\gamma^{+} \mathrm{T}$ cell immune responses to recombinant PPE44 in at least a very high proportion of PPD ${ }^{+}$individuals tested and, to a lower extent, in subjects vaccinated with BCG. By the use of a panel of overlapping synthetic 20-mer peptides spanning the PPE44 primary amino acid sequence, we identified a strong CD4 ${ }^{+}$T-cell epitope, encompassed by peptide p1L (VDFGALPPEVNSARMYGGAG), in the $\mathrm{NH}_{2}$-terminus of the PPE44 molecule at the amino acid position 1-20. Conversely, our experiments did not provide evidence of a significant IFN- $\gamma^{+} \mathrm{CD}^{+} \mathrm{T}$ cell response to PPE44 or its immunodominant peptide $\mathrm{p} 1 \mathrm{~L}$ in most (7 out of 8) patients with active TB.
\end{abstract}

Conclusions: Our data suggest an important immunological role of PPE44 and its immunodominant epitope p1L that could be useful in the design of anti-tuberculosis vaccines and in the immunological diagnosis of $M$.

tuberculosis infection.

\section{Background}

Tuberculosis (TB) is the most significant bacterial infection of humans worldwide involving an estimated 2 billion people, that is one third of the world's population [1]. The host's immune system plays a central role in the progression of TB infection; it is in fact estimated that about $5-10 \%$ of individuals that become infected with Mycobacterium tuberculosis develop active pulmonary $\mathrm{TB}$ and become infectious, while the large majority develop latent infection due to the immunological containment of infection in specific granulomas where tubercle bacilli do not multiply, but persist in a dormant state without provoking any clinical symptoms [2,3]. Latent

\footnotetext{
* Correspondence: laura.rindi@med.unipi.it

Dipartimento di Patologia Sperimentale, Biotecnologie Mediche,

Infettivologia ed Epidemiologia, Università di Pisa, I-56127 Pisa, Italy
}

TB may undergo reactivation when the immune system is less efficient, for example due to HIV infection, malnutrition, aging or other causes. As it is estimated that 1 in 10 individuals infected with $M$. tuberculosis will develop active TB in their lifetime [4], latent infection represents a huge reservoir for new TB cases.

At present, the main strategies pursued to improve TB control are more rapid case-finding, efficient drug treatment and the development of a new $\mathrm{TB}$ vaccine, more effective than the currently available Mycobacterium bovis bacille Calmette-Guérin (BCG). There is therefore a pressing need to detect new TB antigens to set up sensitive immunological tests that may improve the identification of latent TB and to develop effective vaccines capable of activating the immune responses relevant for protection. A Th1-type immune response, based on
C Biomed Central

(c) 2011 Cuccu et al; licensee BioMed Central Ltd. This is an Open Access article distributed under the terms of the Creative Commons Attribution License (http://creativecommons.org/licenses/by/2.0), which permits unrestricted use, distribution, and reproduction in any medium, provided the original work is properly cited. 
MHC class II-restricted $M$. tuberculosis-specific $\mathrm{CD}^{+} \mathrm{T}$ cells producing IFN- $\gamma$, is considered essential for immunological containment of $M$. tuberculosis infection, although different immune cell subsets, such as $\alpha \beta^{+}$ $\mathrm{CD} 8^{+}$or $\gamma \delta^{+} \mathrm{T}$ cells, or other unconventional T cells, namely CD1-restricted $\alpha \beta^{+}$T cells, contribute to immune protection $[5,6]$.

In the last years, our group has identified a novel antigen of M. tuberculosis, protein PPE44 (Rv2770c), belonging to the "PPE proteins", a family of 69 polymorphic proteins of $M$. tuberculosis, defined on the basis of the amino acid (aa) motif Pro-Pro-Glu. Together with the PE (Pro-Glu) proteins, they account for approximately 10\% of the coding capacity of $M$. tuberculosis genome [7]. PPE proteins are characterized by a conserved $\mathrm{NH}_{2}$-terminus domain of approximately 180 aa residues and a C-terminal domain variable in sequence and length; although their role in $M$. tuberculosis infection is unknown, their polymorphic nature suggests that they represent antigens of immunological relevance [8]. In our past studies, we reported that infection of mice with BCG or with $M$. tuberculosis induced PPE44-specific humoral and cellular immune responses $[9,10]$ and, most importantly, vaccination of mice with PPE44-based subunit vaccines followed by an intratracheal challenge with virulent $M$. tuberculosis resulted in protective efficacy comparable to that afforded by BCG [10]. This finding makes PPE44 a promising antigen candidate for TB subunit vaccines.

In the present work, we evaluated the cellular immune response to PPE44 during mycobacterial infection by determining the T-cell response to PPE44 in a small cohort of subjects. Moreover, by the use of synthetic peptides spanning the PPE44 molecule, we mapped a human immunodominant epitope potentially useful for the development of new subunit TB vaccines and immunological diagnosis of TB.

\section{Results}

\section{Human T cell response to rPPE44}

We first determined the number of PBMC producing IFN- $\gamma$ to recombinant PPE44 (rPPE44) by ELISpot in 5 $\mathrm{PPD}^{-}$(negative controls), $5 \mathrm{PPD}^{+}, 4$ BCG-vaccinated subjects and 8 patients with active TB. As shown in Figure 1A, no IFN- $\gamma$-secreting spots were observed in any but one $\mathrm{PPD}^{-}$healthy donors; two out of 4 subjects vaccinated with BCG responded to rPPE44 by producing 10 and 16 spots per $5 \times 10^{4}$ cells, respectively. All healthy $\mathrm{PPD}^{+}$individuals responded to $\mathrm{rPPE} 44$ yielding the highest numbers (18-71) of IFN- $\gamma$-secreting spots. Importantly, for patients with active $\mathrm{TB}$, the responders to rPPE44, as well as the numbers of IFN- $\gamma$ SFU, were significantly lower $(\mathrm{P}<0.005$, at least $)$ than $\mathrm{PPD}^{+}$subjects, as only 1 of 8 responded to rPPE44 yielding relatively few spots (13 SFU).

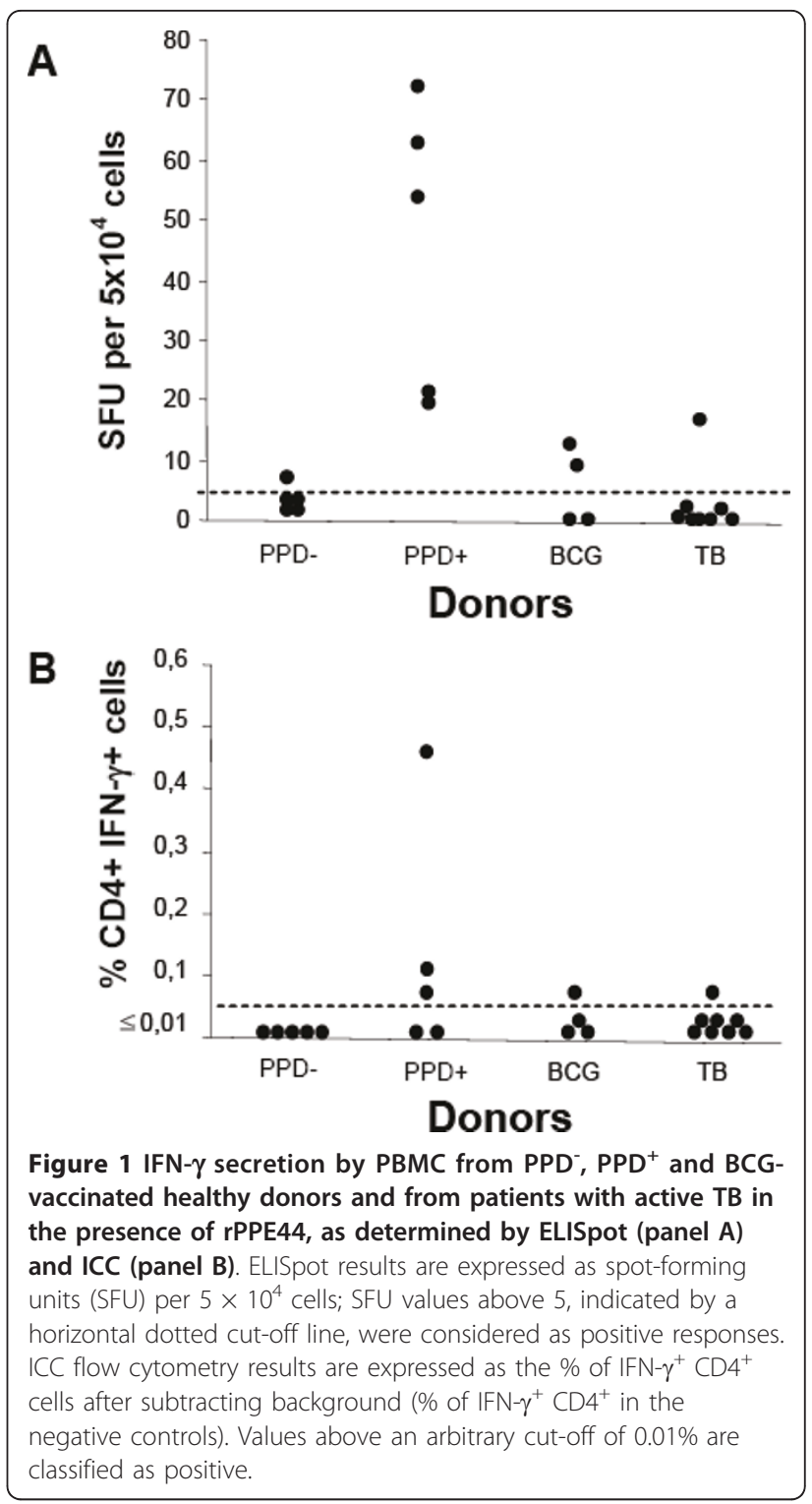

To ascertain that PPE44-specific responses were accounted by $\mathrm{CD} 4^{+} \mathrm{T}$ cells, we performed ICC assays measuring the frequency of PPE44-specific CD4 $4^{+} \mathrm{T}$ cells producing IFN- $\gamma$. As shown in Figure 1B, the frequency of PPE44-specific CD4 $4^{+} \mathrm{T}$ cells producing IFN- $\gamma$ was lower than cut-off in all PPD $^{-}$healthy donors; 3 out of 5 $\mathrm{PPD}^{+}$healthy donors yielded the highest positive responses $(0.46 \%)$. These results probably reflect the lower sensitivity of flow cytometry compared to ELISpot, as shown by other authors as well [11].

\section{Human T cell responses to PPE44 synthetic peptides}

The next experiments were aimed at mapping PPE44 Tcell epitope(s) by studying T-cell immune response in 3 of $5 \mathrm{PPD}^{+}$healthy volunteers used in previous experiment; the 3 subjects chosen tested positive to tuberculin-skin 
test and Quantiferon TB Gold test. Donors' PBMC were stimulated with a panel of synthetic 20 -mer peptides, most of which overlapped by 10 aa, spanning most of the 382 aa sequence of PPE44 and peptide-specific immune responses were then evaluated by ELISpot. As shown in Figure 2, PBMC from all the donors reacted with control rPPE44, as expected, generating numbers of IFN- $\gamma$-specific SFU ranging from 25 to 95 per $5 \times 10^{4}$ cells; only one peptide, i.e., peptide p1L (VDFGALPPEVNSARMYGGAG), spanning aa 1-20 of PPE44, was efficiently recognized by PBMC from all the donors. With regards to the other peptides tested, one donor responded weakly to p6L, p9L, p11L, p12L, p21L, p22L and p30L, yielding 6 to 9 peptidespecific SFU per $5 \times 10^{4}$ cells, while for the other donors spots were generally lower than 5 per $5 \times 10^{4}$ cells or absent for all peptides other than p1L. No IFN- $\gamma$-positive spots were observed towards p18L (SHITNPAGLAHQAAAVGQAG), spanning aa 171-190, in any of the donors tested. Peptide p18L was therefore chosen as a negative control for subsequent experiments.

These results suggested that p1L represents an immunodominant T-cell epitope of protein PPE44.

\section{Human T cell responses to p1L peptide}

The T-cell immune response to $\mathrm{p} 1 \mathrm{~L}$ was then studied in $\mathrm{PPD}^{-}, \mathrm{PPD}^{+}$and BCG-vaccinated healthy individuals and in patients with active TB by ELISpot and flow cytometry; PPD and ESAT-6 were included as controls. In PPD healthy donors, practically no IFN- $\gamma$-producing cells were observed in response to p1L, PPD and ESAT-6, as expected (Figure 3A). Conversely, all $\mathrm{PPD}^{+}$healthy donors (Figure $3 \mathrm{~B}$ ) yielded the highest numbers of IFN- $\gamma$ - producing cells in response to p1L (13 to 78 spots) and PPD (12 to 58 spots); among the PPD ${ }^{+}$healthy donors, 3 out of 5 responded to ESAT- 6 (8, 18 and 51 spots, respectively) and one donor responded to control peptide p18L (16 spots) (Figure 3B). A weak IFN- $\gamma$ response was observed to peptide p1L (11 spots) and antigen ESAT-6 (8 spots) in one of the subjects vaccinated with BCG (Figure 3C); two subjects responded to PPD (22 and 27 spots, respectively) and one subject responded to $\mathrm{p} 18 \mathrm{~L}$ (45 spots). In the 8 patients with active TB (Figure 3D), the response to $\mathrm{p} 1 \mathrm{~L}$ peptide was absent or very poor, as only one patient produced a number of IFN- $\gamma$-positive spots indicative of an immune response (13 spots). The difference from $\mathrm{PPD}^{+}$subjects is significant both in terms of proportion of responders and numbers of IFN- $\gamma$ spots $(\mathrm{P}<0.005)$. Among TB patients, 6 and 4 subjects responded to PPD and ESAT-6, respectively, which is not statistically significant compared to the $\mathrm{PPD}^{+}$group.

On the whole, results obtained by ICC (Figure 4A-D) were comparable to those obtained by ELISpot and confirmed that most $\mathrm{PPD}^{+}$patients $(60 \%$ positivity by ICC versus $100 \%$ by ELISpot) had a detectable immune response to $\mathrm{p} 1 \mathrm{~L}$ peptide, while none of the patients with active TB exhibited a response to $\mathrm{p} 1 \mathrm{~L}$ peptide. Again, although flow cytometry is less sensitive compared to ELISpot [11], it proves that reacting subjects secrete IFN $-\gamma$ via their $\mathrm{CD} 4^{+}$ $\mathrm{T}$ cells. In the responders, the frequency of specific IFN $-\gamma^{+}$ $\mathrm{T}$ cells was significantly higher than cut-off and reached levels of $0.51 \%$. Among BCG-vaccinated donors, a weak response to $\mathrm{p} 1 \mathrm{~L}$ was observed in only one donor.

An example of the ICC analysis for peptide $\mathrm{p} 1 \mathrm{~L}$ and rPPE44 of PBMC obtained from a $\mathrm{PPD}^{+}$donor is given

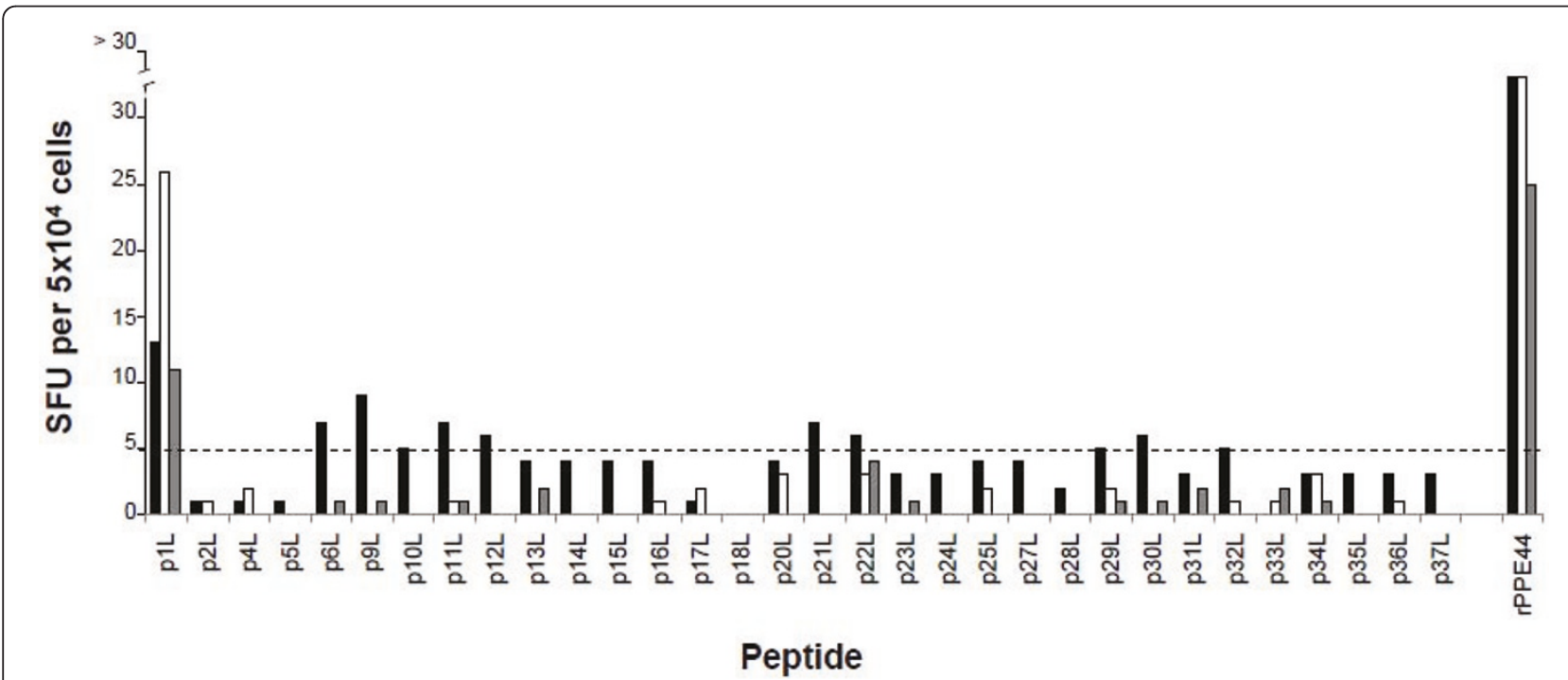

Figure 2 IFN- $\gamma$ secretion by PBMC from 3 PPD $^{+}$healthy donors in the presence of synthetic 20-mer peptides and rPPE44 (positive control), as determined by ELISpot. Individual responses to the peptides are indicated as solid, grey and empty bars. Results are expressed as in Fig. 1A. 
A

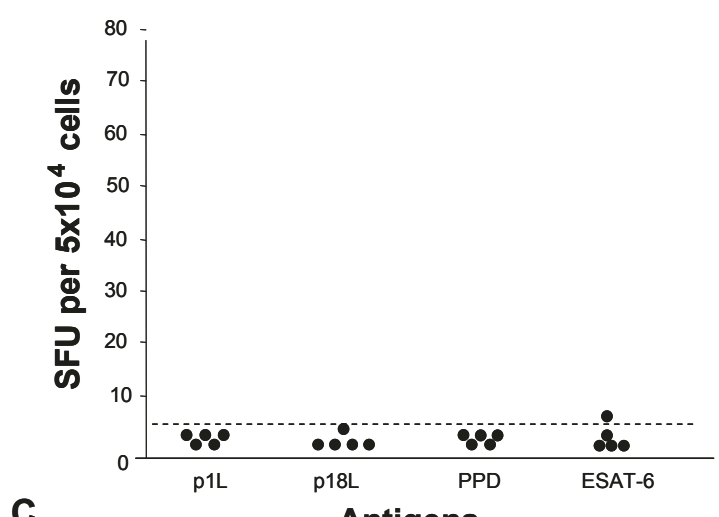

C

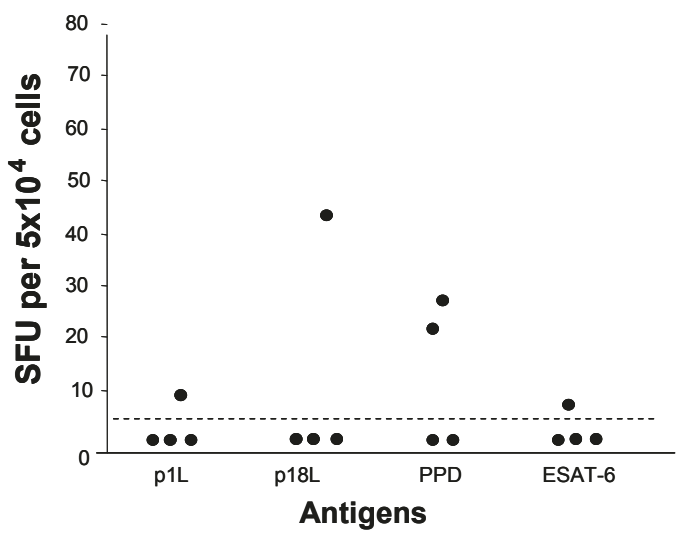

B

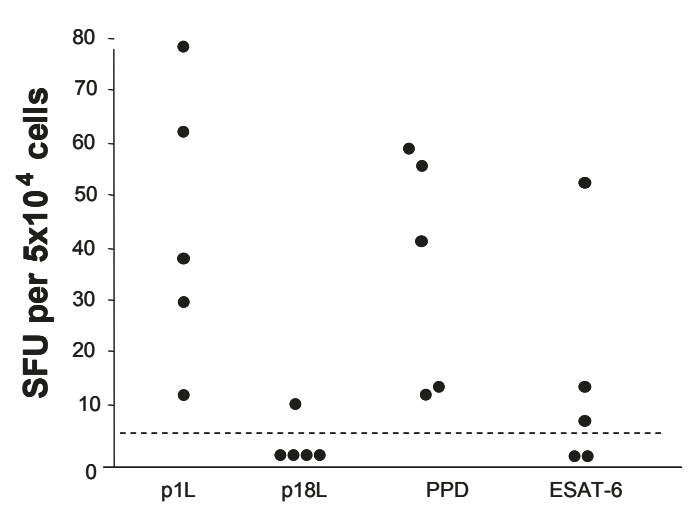

D

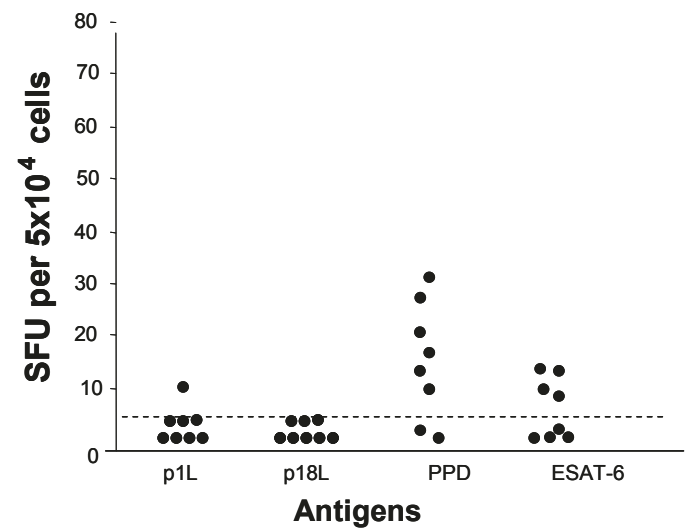

Figure 3 IFN- $\gamma$ secretion by PBMC from PPD- (A), PPD ${ }^{+}$(B) and BCG-vaccinated (C) healthy donors and from patients with active TB (D) in the presence of p1L, p18L, PPD and ESAT-6, as determined by ELISpot. Results are expressed as in Fig. 1A.

in Figure 5B-C. As can be seen, no reactivity was detected either against $\mathrm{p} 1 \mathrm{~L}$, or against rPPE44 in the CD4 population of cells. Thus, $\mathrm{p} 1 \mathrm{~L}$ is recognized by all $\mathrm{PPD}^{+}$healthy subjects tested by ELISpot and reactivity is accounted for by $\mathrm{CD} 4^{+}$cells.

\section{Discussion}

The results reported in this paper show that an IFN $-\gamma^{+} \mathrm{T}$ cell immune response to PPE44 can be detected by ELISpot in all healthy individuals naturally $\mathrm{PPD}^{+}$and, to a lower extent, in subjects vaccinated with BCG; CD4 ${ }^{+} \mathrm{T}$ lymphocytes account for IFN- $\gamma$ secretion in PPE44responder subjects, as shown by ICC analysis. By the same approaches, our study has highlighted the presence of a strong CD4 $4^{+} \mathrm{T}$-cell epitope in the $\mathrm{NH}_{2}$-terminus of the PPE44 molecule localized at the aa position 1-20. Conversely, no significant IFN $-\gamma^{+} \mathrm{CD} 4^{+} \mathrm{T}$ cell response to PPE44 or its immunodominant peptide $\mathrm{p} 1 \mathrm{~L}$ could be detected in most patients (7 out of 8 ) with newly diagnosed active TB.

The PPE44 immunodominat T-cell epitope detected in the present study has been previously reported as the antigenic target of an IL-2-induced IFN- $\gamma^{+}$response in mice in which immunization with PPE44-subunit vaccines conferred protective immunity in an experimental model of TB [10]. The data reported in this paper suggest that IFN$\gamma^{+}$T-cell responses to PPE44 may be associated to immune protection also in human M. tuberculosis infection: indeed, IFN- $\gamma^{+}$T-cells specific for the immunodominant PPE44 peptide p1L were detectable in all individuals whose immune system is likely to have determined the containment of infection and prevented progression to active $\mathrm{TB}$ disease ( $\mathrm{PPD}^{+}$healthy subjects), as well as in a proportion of BCG-vaccinated subjects. On the other hand, most patients with active TB, i.e., those individuals whose immune system failed to contain TB infection, did not respond to PPE44 or p1L. In this respect, however, it has to be considered that TB patients enrolled in our study were under TB chemotherapy, which might have decreased the $M$. tuberculosis-specific IFN- $\gamma$ responses $[12,13]$; another explanation might be that PPE44-specific $\mathrm{T}$ cells are sequestered at the site of mycobacterial replication, usually the lung. Alternatively, it is tempting to speculate that the poor $\mathrm{T}$-cell immune responsiveness of $\mathrm{TB}$ patients to $\mathrm{p} 1 \mathrm{~L}$ might be related to a dynamic antigen 
A

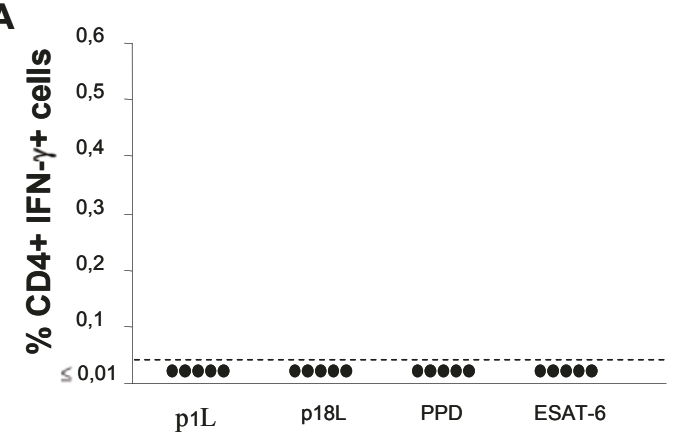

C

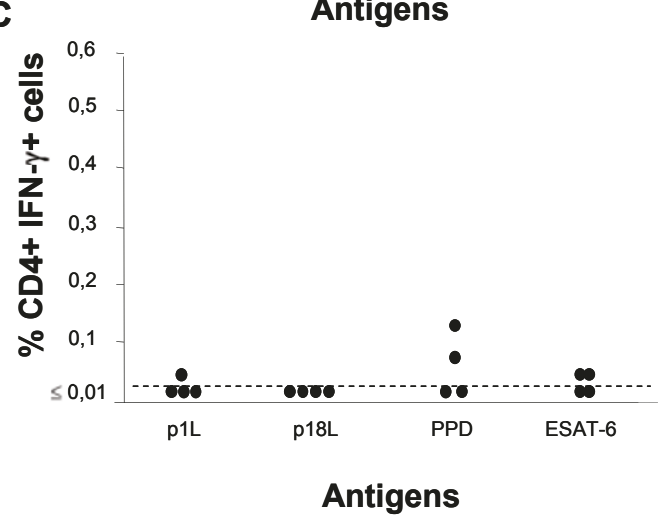

B

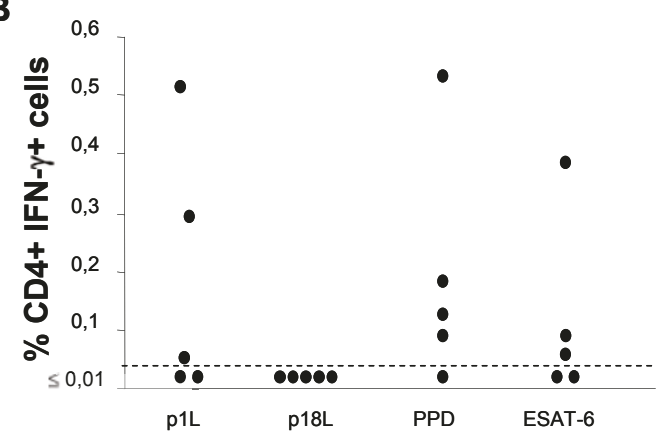

D

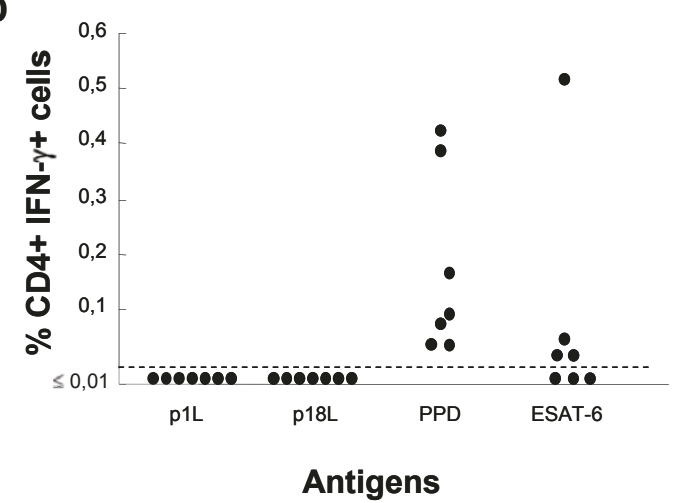

Figure 4 IFN- $\gamma$ secretion by PBMC from PPD- (A), PPD ${ }^{+}$(B) and BCG-vaccinated (C) healthy donors and from patients with active TB (D) in the presence of $\mathrm{p} 1 \mathrm{~L}, \mathrm{p} 18 \mathrm{~L}, \mathrm{PPD}$ and ESAT-6, as determined by ICC flow cytometry. Results are expressed as in Fig. 1B.

display due to differential expression of PPE44 during active infection; indeed, in a previous paper, we reported great variations in the expression of the gene coding for PPE44 among $M$. tuberculosis isolates and that only about one third of patients with active TB produced antibodies to PPE44 [14]. A last attractive hypothesis could be that a $\mathrm{T}$ cell response to $\mathrm{p} 1 \mathrm{~L} / \mathrm{PPE} 44$ helpes individuals to contain TB infection, while those who do not mount such a response are more prone to develop active disease.

One of the promising features of $\mathrm{p} 1 \mathrm{~L}$ is that it was recognized by all $5 \mathrm{PPD}^{+}$healthy individuals tested, as shown by ELISpot, suggesting that $\mathrm{p} 1 \mathrm{~L}$ is most probably able to bind a number of human HLA-DR alleles. It also proved to be immunodominant in two different species, being a T-cell epitope also in the C57BL/6 strain of mice [10]. "Promiscuous" helper peptides are peptides that can bind a wide range of MHC class II alleles. Within their sequence, they typically have a motif, called P1-P6, where position 1 can be an aromatic or a hydrophobic aa whereas position 6 can be a small or hydrophobic aa [15]. Indeed, such motif can be found in 3 positions in $\mathrm{p} 1 \mathrm{~L}$, namely 1-6, 3-8 and 10-6. Promiscuous peptides have been searched for and described both in mycobacterial antigens [16] and in other antigens, such as the malarial circumsporozoite protein [17]. They allow to overcome the problem of the high degree of polymorphism of the HLA-DR molecules expressed in the human population and for such a reason they are ideal candidates for subunit vaccine design and as diagnostic tools. To this aim, future studies will attempt to establish the HLA class II restriction elements binding p1L.

Two other PPE proteins of $M$. tuberculosis have proven capable of inducing protection against M. tuberculosis in experimental models, namely i) the PPE14 (Rv0915c/ Mtb41), that has shown promising vaccine potential in human clinical trials [18], and ii) the PPE18 (Mtb39A/ Rv1196), that is a component of the subunit vaccine Mtb72F. The latter has recently been investigated in clinical trials showing good tolerability and immunogenicity in humans [19,20]. Dillon et al. [21] have reported proliferative response towards aa 1-20 of PPE18 in PBMC from PPD-positive human subjects, that is exactly the PPE region were our studies have mapped the $\mathrm{CD} 4^{+} \mathrm{T}$ cell epitope. Indeed, the immunodominant $\mathrm{p} 1 \mathrm{~L}$ domain shows 60 to $85 \%$ aa homology with the corresponding sequences of 30 PPE proteins of $M$. tuberculosis and, in particular, p1L shares 14 identical aa with the $\mathrm{NH}_{2}$-terminal 20-aa sequence of the protective antigens PPE18 and PPE14. These observations raise the possibility that cross-reactivity might have contributed to the strong 

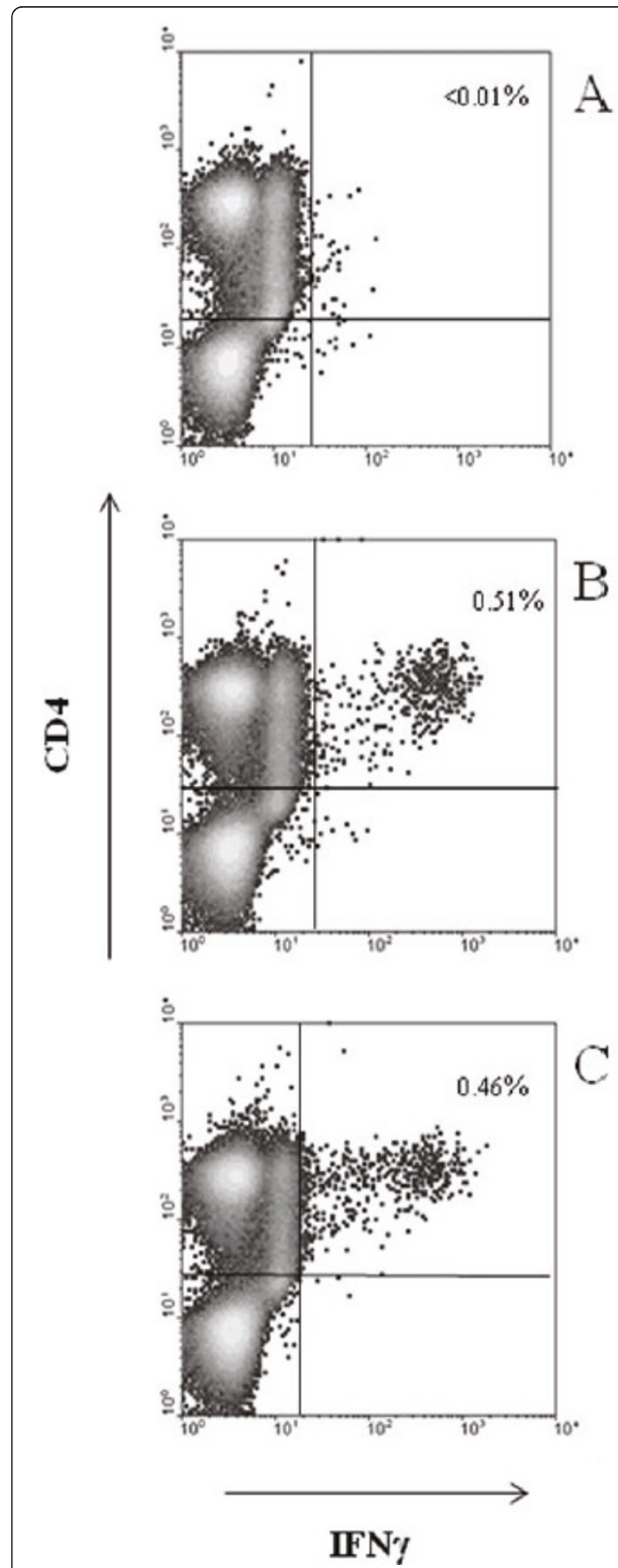

Figure 5 Representative examples of ICC flow cytometry analysis of PBMC in response to $\mathrm{P} 1 \mathrm{~L}$ and rPPE44. The percentage of $\mathrm{IFN}-\gamma^{+} \mathrm{CD}^{+}$cells is given in the upper right corner of each panel. Panel A, PBMC from a PPD healthy donor in the presence of P1L; panel B and C, PBMC of a PPD ${ }^{+}$healthy donor in the presence of $\mathrm{P} 1 \mathrm{~L}$ and $\mathrm{rPPE} 44$, respectively. immunogenicity of the conserved and homologous $\mathrm{NH}_{2}$-terminal regions of the PPE proteins. These considerations make PPE proteins, especially their immunodominant $\mathrm{NH}_{2}$-terminal domains, promising antigen candidates for TB subunit vaccine development.

Latent TB infection is conventionally screened for by the more-than-100-year-old tuberculin skin test, that measures in vivo reactivity to tuberculin or PPD, a mixture of mycobacterial antigens, some of which common to non-tuberculous mycobacteria and to the vaccine strain M. bovis BCG. Recently, assays based on release of IFN- $\gamma$ by PBMC exposed in vitro to M. tuberculosisspecific antigens, such as ESAT-6 and CFP-10, have emerged as attractive specific alternatives to tuberculin skin test to distinguish between $M$. tuberculosis infection and BCG vaccination/reactivity to non-tuberculous mycobacteria [22,23]. However, the sensitivity of both tuberculin skin test and IFN- $\gamma$-release assays is suboptimal, and none of these tests distinguish between latent infection and active disease [24]. In this context, PPE44 might turn out as a useful reagent for the immunological diagnosis of latent $\mathrm{TB}$ and $\mathrm{p} 1 \mathrm{~L}$ could prove even more useful than the whole recombinant protein becauseT cell reactivity, especially in thawed PBMC, has often been reported to be higher towards synthetic peptides than to recombinant proteins [25]. Our data indicate that a PPE44- or $\mathrm{p} 1 \mathrm{~L}-$-specific IFN $-\gamma^{+} \mathrm{T}$ cellresponse occurs in naturally $\mathrm{PPD}^{+}$individuals, who are likely to harbour latent TB infection, and in a proportion of BCG vaccinees tested, but it is not detectable in most of our patients with active TB. These results, although very preliminary, would make $\mathrm{p} 1 \mathrm{~L}$ a good candidate, in association with the other TB-specific antigens available, to distinguish between latent infection and active disease.

\section{Conclusions}

The present report identifies p1L (PPE44 aa 1-20) as an immunodominant promiscuous peptide that is worth studiyng further both as a vaccine component and as a diagnostic reagent.

\section{Methods}

\section{Study subjects and ethics statement}

Study subjects included 5 purified protein derivative negative (PPD-) and 5 PPD positive (PPD+) healthy donors, 4 subjects vaccinated with $M$. bovis BCG (BCG), and 8 patients with active $\mathrm{TB}$, as shown by culture isolation of M. tuberculosis, recruited from Hospital "SS. Giacomo e Cristoforo", Massa, Italy. Reactivity to PPD was determined on PBMC in vitro by ELISpot. The study was approved by the Ethics Committee of Hospital "SS. Giacomo e Cristoforo", Massa, Italy and written informed consent was obtained from all subjects. 
Recombinant PPE44, synthetic peptides, and $M$. tuberculosis antigens

rPPE44 was produced in our laboratory; cloning, expression and purification have been previously reported [9].

A panel of 20 -mer peptides, overlapping by 10 aa residues, spanning the entire 382-aa PPE44 sequence except for aa 71-80, was synthesized by ProImmune (Oxford, UK); peptide spanning aa 61-80 could not be synthesized due to technical reasons; aa sequence and position of peptides are given in Table 1. Peptides were initially dissolved in DMSO and stock solutions were prepared in RPMI1640 medium at $1 \mathrm{mg} / \mathrm{ml}$ and stored in aliquots at $-20^{\circ} \mathrm{C}$ until use.

PPD and ESAT-6 (Early Secretory Antigen T-6) whole recombinant protein were purchased from Statens Serum Institut (Copenhagen, Denmark).

Table 1 Amino acid sequence of synthetic peptides of PPE44 used in this study

\begin{tabular}{|c|c|}
\hline Peptide (position) & Amino acid sequence \\
\hline p1L (1-20) & VDFGALPPEVNSARMYGGAG \\
\hline p2L (11-30) & NSARMYGGAGAADLLAAAAA \\
\hline p4L (31-50) & WNGIAVEVSTAASSVGSVIT \\
\hline p5L (41-60) & AASSVGSVITRLSTEHWMGP \\
\hline p6L (51-70) & RLSTEHWMGPASLSMAAAVQ \\
\hline p9l (81-100) & ESSALAAAQAMASAAAFETA \\
\hline p10L (91-110) & MASAAAFETAFALTVPPAEV \\
\hline p11L (101-120) & FALTVPPAEWANRALLAEL \\
\hline p12L (111-130) & VANRALLAELTATNILGQNV \\
\hline p13L (121-140) & TATNILGQNVSAIAATEARY \\
\hline p14L (131-150) & SAIAATEARYGEMWAQDASA \\
\hline p15L (141-160) & GEMWAQDASAMYGYAAASAV \\
\hline p16L (151-170) & MYGYAAASAVAARLNPLTRP \\
\hline p17L (161-180) & AARLNPLTRPSHITNPAGLA \\
\hline p18L (171-190) & SHITNPAGLA HQAAAVGQAG \\
\hline p20L (191-210) & ASAFARQVGLSHLISDVADA \\
\hline p21L (201-220) & SHLISDVADAVLSFASPVMS \\
\hline p22L (211-230) & VLSFASPVMSAADTGLEAVR \\
\hline p23L (221-240) & AADTGLEAVRQFLNLDVPLF \\
\hline p24L (231-250) & QFLNLDVPLFVESAFHGLGG \\
\hline p25L (241-260) & VESAFHGLGGVADFATAAIG \\
\hline p27L (261-280) & NMTLLADAMGTVGGAAPGGG \\
\hline p28L (271-290) & TVGGAAPGGGAAAAVAHAVA \\
\hline p29L (281-300) & AAAAVAHAVAPAGVGGTALT \\
\hline p30L (291-310) & PAGVGGTALTADLGNASWG \\
\hline p31L (301-320) & ADLGNASWGRLSVPASWST \\
\hline p32L (311-330) & RLSVPASWSTAAPATAAGAA \\
\hline p33L (321-340) & AAPATAAGAALDGTGWAVPE \\
\hline p34L (331-350) & LDGTGWAVPEEDGPIAVMPP \\
\hline p35L (341-360) & EDGPIAVMPPAPGMWAANS \\
\hline p36L (351-370) & APGMWAANSVGADSGPRYG \\
\hline p37L (363-382) & ADSGPRYGVKPIVMPKHGLF \\
\hline
\end{tabular}

Peripheral blood mononuclear cells

Peripheral blood mononuclear cells (PBMCs) were isolated from donors' heparinized blood by Lympholyte-H (Cederlane, Canada) density gradient centrifugation. Briefly, blood was layered over an equal volume of Lympholyte- $\mathrm{H}$ and centifuged at $800 \mathrm{~g}$ for 30 minutes at room temperature. The layer of PBMC was removed and washed twice at 500 and $200 \mathrm{~g}$ for 10 minutes in RPMI-1640 medium. Cells were suspended in culture medium consisting of RPMI1640 medium supplemented with $2 \mathrm{mM}$ L-glutamine, $100 \mathrm{U} / \mathrm{ml}$ penicillin, $100 \mu \mathrm{g} / \mathrm{ml}$ streptomycin and $10 \%$ fetal calf serum or $3 \%$ autologous plasma. All culture reagents were from Sigma-Aldrich (Milan, Italy)

\section{Enzyme-linked immunospot assay (ELISpot)}

The ELISpot reagent kit was purchased from Pierce Biotechnology (Rockford, USA) and the assay was performed according to the manufacturers' recommendations. In brief, $5 \times 10^{4}$ PBMC in a $50 \mu$ l-volume of culture medium were plated onto multiscreen 96 -well polyvinylidene fluoride membrane bottom plates coated with IFN- $\gamma$-specific antibody. A $50 \mu \mathrm{l}$-volume of medium alone (negative control), medium containing phorbol 12-myristate 13-acetate (PMA)/ionomycin (positive control), or test antigens was added and plates were incubated for $16-24 \mathrm{hr}$ at $37^{\circ} \mathrm{C}$ in $5 \% \mathrm{CO}_{2}$. Test antigens were used at the following final concentrations: rPPE44, $10 \mu \mathrm{g} / \mathrm{ml}$; synthetic peptides, $10 \mu \mathrm{g} / \mathrm{ml}$; PPD, $10 \mu \mathrm{g} / \mathrm{ml}$; ESAT-6, $5 \mu \mathrm{g} / \mathrm{ml}$. PMA and ionomycin were used at $1 \mathrm{ng} / \mathrm{ml}$ and $500 \mathrm{ng} / \mathrm{ml}$, respectively. The plates were subsequently washed and incubated for $1 \mathrm{hr}$ with a biotin-labeled anti-human IFN- $\gamma$ antibody. After a subsequent wash, the plates were incubated with alkaline phosphatase-labeled streptavidin for $1 \mathrm{hr}$ and then developed using a solution of nitro-blue tetrazolium chloride as substrate. Spots were counted using an automated image analysis system ELISpot reader (AID, Strassburg, Germany). Usually, ELISpot results were classified as valid when spots in wells with medium alone were less than 5 and spots in the presence of PMA/ionomycin were greater than 20. T-cell responses to tested antigens were classified as positive when the numbers of spots were greater than 5 .

\section{Intracellular cytokine cytometry}

Two $\times 10^{6}$ PBMC were incubated in polypropylene tubes in $0.5 \mathrm{ml}$ of culture medium alone (negative control) or in the same volume of medium containing PMA/ionomycin at final concentrations of $10 \mathrm{ng} / \mathrm{ml}$ and $250 \mathrm{ng} / \mathrm{ml}$, respectively (positive control), or test antigens at the following final concentrations: rPPE44, $1 \mu \mathrm{g} / \mathrm{ml}$; synthetic peptides, $1 \mu \mathrm{g} / \mathrm{ml}$; PPD, $10 \mu \mathrm{g} / \mathrm{ml}$; ESAT-6, $5 \mu \mathrm{g} / \mathrm{ml}$. Costimulatory antibodies CD28 and CD49d (eBioscience, San Diego, CA, USA) at the concentration of $0.5 \mu \mathrm{g} / \mathrm{ml}$ were added to all tubes, except for the PMA/ionomycin tube [26]. After 1 -hr activation at $37^{\circ} \mathrm{C}$ in $5 \% \mathrm{CO}_{2}$, 
brefeldin A, $10 \mu \mathrm{g} / \mathrm{ml}$, (Sigma-Aldrich) was added to each tube. After a 6-hr incubation, cells were fixed in ice with $1 \mathrm{ml}$ of $1 \%$ paraformaldehyde in PBS, washed in FACS buffer (PBS, $2 \%$ FCS, $0,1 \% \mathrm{NaN}_{3}$ ) and permeabilized in $0,1 \%$ saponin. Surface and intracellular staining were carried out in the dark for $1 \mathrm{hr}$ with $4 \mu \mathrm{l}$ PE-labeled antiCD4 (Miltenyi Biotec, Bergish Gladbach, Germany) and $0.5 \mu$ l FITC-labeled anti-IFN- $\gamma$ (eBioscience) monoclonal antibodies. Cells were finally washed in FACS buffer/ $0.1 \%$ saponin, resuspended in FACS buffer and analyzed by flow cytometry (FACSCan, Becton Dickinson, San Jose, USA). Viable lymphocytes were gated by forward and side light scatter and 250,000 CD4 ${ }^{+}$lymphocytes events were acquired for each sample and analyzed with the CellQuest software. The frequencies of $\mathrm{CD} 4^{+}$IFN- $\gamma^{+}$ events are given as percentages of total $\mathrm{CD} 4^{+}$cells after subtracting background $\left(\% \mathrm{CD} 4^{+}\right.$IFN $-\gamma^{+}$cells in the negative controls). Values above an arbitrary cut-off of $0.01 \% \mathrm{CD}^{+} \mathrm{T}$ cells were classified as positive responses on the basis of previous studies of $\mathrm{CD} 4^{+} \mathrm{T}$-cell responses to $M$. tuberculosis antigens [25,27].

\section{Statistical analysis}

Fisher exact test was used to compare the numbers of responders and nonresponders to antigenic stimuli; oneway analysis of variance with post tests was used to determine variations among responses. All test were performed by the InStat software package (GraphPad, San Diego, CA, USA); P values less than 0.05 were considered to indicate statistical significance.

\footnotetext{
Acknowledgements

This work was financially supported by MIUR (PRIN-2006 and 2007) and, partly, by the Italian Istituto Superiore di Sanità (National Research Program on AIDS-2006, ISS grant 50G.18).

We are grateful to patients and physicians of the Infectious Diseases Units of Hospital "SS. Giacomo e Cristoforo", Massa, Italy, for their valuable collaboration.

\section{Authors' contributions}

$B C$ and $A G$ performed the experiments. GF partecipated in the study design and revised the manuscript. CG partecipated in the general supervision of partecipated in its design and drafting and revision of the manuscript. All authors read and approved the final version of the manuscript.
\end{abstract} the research and critical revision of the manuscript. LR conceived the study,
}

\section{Competing interests}

The authors declare that they have no competing interests.

Received: 23 February 2011 Accepted: 25 July 2011

Published: 25 July 2011

\section{References}

1. World Health Organization. Report 2010: Global tuberculosis control. [http://www.who.int/tb/publications/global_report/2010/en].

2. Barry CE, Boshoff HI, Dartois V, Dick T, Ehrt S, Flynn J, Schnappinger D, Wilkinson RJ, Young D: The spectrum of latent tuberculosis: rethinking the biology and intervention strategies. Nat Rev Microbiol 2009, 7:845-855.

3. Lin PL, Flynn JL: Understanding latent tuberculosis: a moving target. $J$ Immunol 2010, 185:15-22.
4. Tufariello JM, Chan J, Flynn JL: Latent tuberculosis: mechanisms of host and bacillus that contribute to persistent infection. Lancet Infect Dis 2003, 3:578-590.

5. Kaufmann SHE: How can immunology contribute to the control of tuberculosis? Nat Rev Immunol 2001, 1:20-30.

6. Cooper AM, Khader SA: The role of cytokines in the initiation, expansion, and control of cellular immunity to tuberculosis. Immunol Rev 2008, 226:191-204

7. Cole ST: Learning from the genome sequence of Mycobacterium tuberculosis H37Rv. FEBS Let 1999, 452:7-10.

8. Cole ST, Brosch R, Parkhill J, Garnier T, Churcher C, Harris D, Gordon SV, Eiglmeier K, Gas S, Barry III CE, Tekaia F, Badcock K, Basham D, Brown D, Chillingworth T, Connor R, Davies R, Devlin K, Feltwell T, Gentles S, Hamlin N, Holroyd S, Hornsby T, Jagels K, Krogh A, McLean J, Moule S, Murphy L, Oliver K, Osborne J, Quail MA, Rajandream MA, Rogers J, Rutter S, Seeger K, Skelton J, Squares R, Squares S, Sulston JE, Taylor K, Whitehead S, Barrell BG: Deciphering the biology of Mycobacterium tuberculosis from the complete genome sequence. Nature 1998, 393:537-544.

9. Bonanni D, Rindi L, Lari N, Garzelli C: Immunogenicity of mycobacterial PPE44 (Rv2770c) in Mycobacterium bovis BCG-infected mice. J Med Microbiol 2005, 54:443-448.

10. Romano M, Rindi L, Korf H, Bonanni D, Adnet PY, Jurion F, Garzelli C, Huygen K: Immunogenity and protective efficacy of tuberculosis subunit vaccines expressing PPE44 (Rv2770c). Vaccine 2008, 26:6053-6063.

11. Karlsson AC, Martin JN, Younger SR, Bredt BM, Epling L, Ronquillo R, Varma A, Deeks SG, McCune JM, Nixon DF, Sinclair E: Comparison of the ELISPOT and cytokine flow cytometry assays for the enumeration of antigen-specific T cells. J Immunol Methods 2003, 283:141-153.

12. Aiken AM, Hill PC, Fox A, McAdam KPWJ, Jackson-Sillah D, Lugos MD, Donkor SA, Adegbola RA, Brookes R: Reversion of the ELISPOT test after treatment in Gambian tuberculosis cases. BMC Infect Dis 2006, 6:66.

13. Sauzullo I, Mengoni F, Lichtner M, Massetti AP, Rossi R, lannetta M, Marocco R, Del Borgo C, Soscia F, Vullo V, Mastroianni CM: In vivo and in vitro effects of antituberculosis treatment on mycobacterial interferon- $\gamma$ T cell response. Plos ONE 2009, 4:e5187.

14. Rindi L, Peroni I, Lari N, Bonanni D, Tortoli E, Garzelli C: Variation of the expression of Mycobacterium tuberculosis ppe44 gene among clinical isolates. FEMS Immunol Med Microbiol 2007, 51:381-387.

15. Southwood S, Sidney J, Kondo A, del Guercio MF, Appella E, Hoffman S, Kubo RT, Chesnut RW, Grey HM, Sette A: Several common HLA-DR types share largely overlapping peptide binding repertoires. J Immunol 1998, 160:3363-3373.

16. Mustafa AS, Lundin KE, Meloen RH, Shinnick TM, Oftung F: Identification of promiscuous epitopes from the mycobacterial 65-kilodalton heat shock protein recognized by human CD4(+) T cells of the Mycobacterium leprae memory repertoire. Infect Immun 1999, 67:5683-5689.

17. Caro-Aguilar I, Rodríguez A, Calvo-Calle JM, Guzmán F, De la Vega P, Patarroyo ME, Galinski MR, Moreno A: Plasmodium vivax promiscuous Thelper epitopes defined and evaluated as linear peptide chimera immunogens. Infect Immun 2002, 70:3479-3492.

18. Skeiky YA, Alderson MR, Ovendale PJ, Lobet Y, Dalemans W, Orme IM, Reed SG, Campos-Neto A: Protection of mice and guinea pigs against tuberculosis induced by immunization with a single Mycobacterium tuberculosis recombinant antigen, MTB41. Vaccine 2005, 23:3937-3945.

19. Skeiky YAW, Alderson MR, Ovendale P, Guderian JA, Brandt L, Dillon DC, Campos-Neto A, Lobet Y, Dalemans W, Orme IM, Reed SG: Differential immune responses and protective efficacy induced by components of a tuberculosis polyprotein vaccine, Mtb72F, delivered as naked DNA or recombinant protein. J Immunol 2004, 172:7618-7628.

20. Von Eschen K, Morrison R, Braun M, Ofori-Anyinam O, De Kock E, Pavithran P, Koutsoukos M, Moris P, Cain D, Dubois MC, Cohen J, Ballou WR: The candidate tuberculosis vaccine Mtb72F/AS02A: tolerability and immunogenicity in humans. Hum Vaccin 2009, 5:475-482.

21. Dillon DC, Alderson MR, Day CH, Lewinsohn DM, Coler R, Bement T, Campos-Neto A, Skeiky YAW, Orme IM, Roberts A, Steen S, Dalemans W, Badaro R, Reed SG: Molecular characterization and human T-cell responses to a member of a novel Mycobacterium tuberculosis mtb39 gene family. Infect Immun 1999, 67:2941-2950.

22. Pai M, Zwerling A, Menzies D: Systematic review: T-cell-based assays for the diagnosis of latent tuberculosis infection: un update. Ann Intern Med 2008, 149:177-184 
23. Parkash $\mathrm{O}$, Singh BP, Pai M: Regions of differences encoded antigens as target for immunodiagnosis of tuberculosis in humans. Scand I Immunol 2009, 70:345-357.

24. Ahmad S: New approaches in the diagnosis and treatment of latent tuberculosis infection. Respir Res 2010, 11:169.

25. Tesfa L, Koch FW, Pankow W, Volk HD, Kern F: Confirmation of Mycobacterium tuberculosis infection by flow cytometry after ex vivo incubation of pheripheral blood T cells with an ESAT-6-derived peptide pool. Cytometry 2004, 60B:47-53.

26. Gaudin MC: Intracellular cytokine staining for the characterization and quantification of antigen-specific T lymphocytes responses. Methods 2006, 38:263-273.

27. Hughes AJ, Hutchinson P, Gooding T, Freezer NJ, Holdsworth R, Johnson PDR: Diagnosis of Mycobacterium tuberculosis infection using ESAT-6 and intracellular cytokine cytometry. Clin Exp Immunol 2005, 142:132-139.

doi:10.1186/1471-2180-11-167

Cite this article as: Cuccu et al.: Identification of a human

immunodominant T-cell epitope of mycobacterium tuberculosis antigen PPE44. BMC Microbiology 2011 11:167.

\section{Submit your next manuscript to BioMed Central} and take full advantage of:

- Convenient online submission

- Thorough peer review

- No space constraints or color figure charges

- Immediate publication on acceptance

- Inclusion in PubMed, CAS, Scopus and Google Scholar

- Research which is freely available for redistribution

Submit your manuscript at www.biomedcentral.com/submit 